\title{
A new record of Leucocintractia scleriae (Anthracoideaceae) from Japan
}

\section{Teodor T. Denchev ${ }^{1 *}$, Tomomi Masaki ${ }^{2}$ \& Cvetomir M. Denchev $^{1}$}

\author{
${ }^{1}$ Institute of Biodiversity and Ecosystem Research, Bulgarian Academy of Sciences, 2 Gagarin St., 1113 \\ Sofia, Bulgaria \\ ${ }^{2}$ Department of Biosphere-Geosphere System Science, Okayama University of Science, Ridai-Cho 1-1, \\ Okayama 700-0005, Japan
}

Received 14 September 2015 / Accepted 23 September 2015 / Published 27 September 2015

Denchev, T.T., Masaki, T. \& Denchev, C.M. 2015. A new record of Leucocintractia scleriae (Anthracoideaceae) from Japan. - Mycobiota 5: 21-25. doi: 10.12664/mycobiota.2015.05.04

Abstract. Leucocintractia scleriae is reported for the first time from Japan.

Key words: Anthracoideaceae, Asia, Cyperaceae, Japan, Leucocintractia, Rhynchospora corymbosa, smut fungi, taxonomy, Ustilaginales

\section{Introduction}

Species of Rhynchospora (Cyperaceae) are distributed worldwide, with greatest diversity in tropical and subtropical regions (mainly in the American savannas). With about 350 species, it is the third-largest cyperaceous genus (Lucero et al. 2014). Eleven Rhynchospora species are known to be distributed in Japan (Hokkaido, Honshu, Shikoku, Kyushu, Ogasawara Islands, and Ryukyu Islands) (Hoshino et al. 2011).

Thirty species of smut fungi, belonging to Cintractia, Kuntzeomyces, Leucocintractia, Moreaua, Testicularia, Trichocintractia, and Ustanciosporium, are recognized on Rhynchospora (Vánky 2010, 2011a, b; Denchev \& Denchev 2015).

The members of Leucocintractia form cylindrical sori around all the pedunculi of an inflorescence or around internodes of the stem of host plants of Rhynchospora. Initially, the sori are covered by a thick, white peridium that later ruptures exposing a black, agglutinated spore mass with a powdery surface. The sori possess a sterile stroma forming sporogenous pockets. The infection is systemic. The spores are single, flattened, without appendages, covered by irregular, rough warts forming ridges at the sides of the spores (Piepenbring et al. 1999; Vánky 2011b, 2013).

\footnotetext{
*Corresponding author: e-mail: ttdenchev@gmail.com
} 
Leucocintractia comprises four species, all of them found on host plants of Rhynchospora: L. leucoderma (Berk.) M. Piepenbr., L. pachyderma (Syd.) M. Piepenbr., L. portus-argenti (Cif.) M. Piepenbr., and L. scleriae (DC.) M. Piepenbr., Begerow \& Oberw. (Vánky et al. 2010, 2011b).

In this article, Leucocintractia scleriae is reported for the first time from Japan. The collection on which this record is based was discovered during a visit to the herbarium of the Naturalis Biodiversity Center, Leiden (L), the Netherlands. This contribution is a part of an ongoing study on the smut fungi on Cyperaceae in Japan (Denchev et al. 2011, 2013; Denchev \& Denchev 2014; Denchev 2015).

\section{Material and methods}

A dried specimen from the herbarium of the Naturalis Biodiversity Center, Leiden (L) was examined with a light microscope (LM) and scanning electron microscope (SEM). For LM observations and measurements, spores were mounted in lactoglycerol solution ( $\mathrm{w}$ : la $: \mathrm{gl}=1: 1: 2$ ) on glass slides, gently heated to boiling point to rehydrate the spores, and then cooled. The measurements of spores are given as min-max (mean \pm 1 standard deviation). For SEM, spores were attached to specimen holders by double-sided adhesive tape and coated with gold in an ion sputter. The surface structure of spores was observed and photographed at $10 \mathrm{kV}$ accelerating voltage using a JEOL JSM-5510 scanning electron microscope. The description given below is based entirely on the specimen examined.

\section{Taxonomy}

Leucocintractia scleriae (DC.) M. Piepenbr., Begerow \& Oberw., Mycologia 91: 497, 1999.

Figs 1-4

Sori around all peduncles of an infected inflorescence, a few rudimentary spikelets present on the distal part of the peduncles; more or less cylindrical, often curved, 4-15 $\times 1-3 \mathrm{~mm}$, when young covered by a peridium, later becoming exposed; spore mass of the mature sori blackish brown, agglutinated, powdery on the surface. Infection systemic. Spores slightly flattened, in plane view orbicular, suborbicular or broadly elliptical, in plane view $(12-) 13-16(-17) \times(11.5-) 12.5-14.5(-15.5)(15.0 \pm 0.8 \times 13.5 \pm 0.7) \mu \mathrm{m}(\mathrm{n}=$ 100), in side view $9.5-12.5 \mu \mathrm{m}$ wide, middle reddish brown; wall evenly thickened, $0.7-$ $1.3 \mu \mathrm{m}$ thick, in $\mathrm{LM}$, in plane view densely, moderately verruculose to verrucose, in side view warts often fused in parallel ridges, spore profile affected. In SEM, in plane view warts connected, forming irregular groups or incomplete reticulum, in side view warts connected, forming irregular meshes, or uneven, more or less parallel ridges, often connected by lower, transverse rows.

Specimen examined - On Rhynchospora corymbosa (L.) Britton: JAPAN, RYUKYU ISLANDS, Okinawa Pref., Okinawa Island, Nago, Nago Park, 9 Jul 1951, leg. E.H. Walker, S. Sonohara, S. Tawada \& T. Amano, no. 6078 (L 1401123).

Distribution: on Rhynchospora asperula (Nees) Steud., $R$. corniculata (Lam.) A. Gray ( $R$. laxa Vahl), R. corymbosa (L.) Britton ( $R$. aurea Vahl), $R$. gigantea Link, $R$ spectabilis Hochst. 


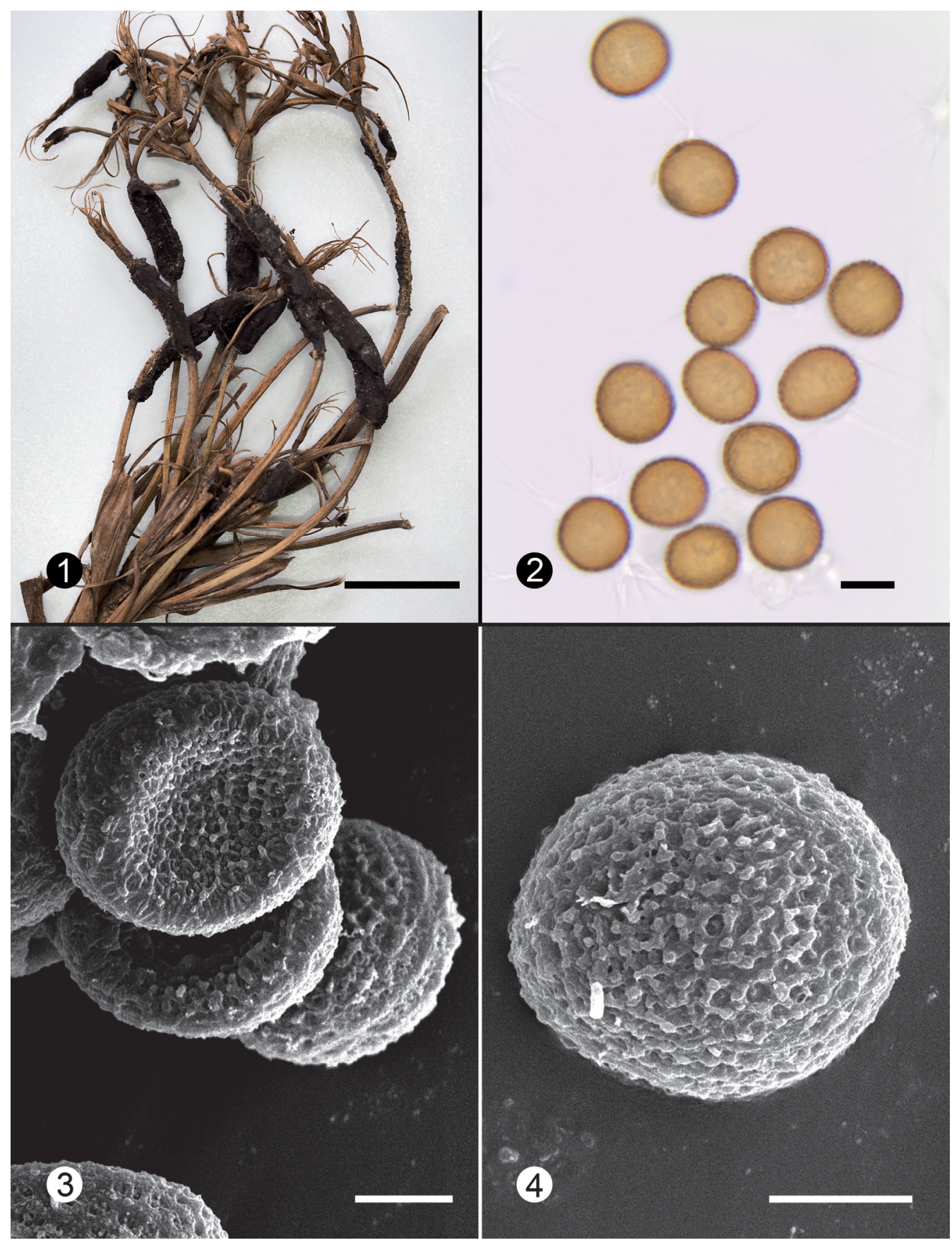

Figs 1-4. Leucocintractia scleriae on Rhynchospora corymbosa (L 1401123). 1. Sori around the peduncles of the infected inflorescence. 2. Spores in LM. 3, 4. Spores in SEM. Scale bars: $1=1 \mathrm{~cm}, 2=10 \mu \mathrm{m}, 3,4=5 \mu \mathrm{m}$ 
ex C. Krauss, R. triflora Vahl, and Rhynchospora sp., common in the tropics and subtropics (Piepenbring 2003; Vánky 2010, 2011b; Vánky et al. 2011; Denchev \& Denchev 2012).

Comments. Rhynchospora corymbosa is a widely distributed species in the tropics and subtropics. In Japan, this species is known from the Ryukyu Islands (Hoshino et al. 2011).

The sori of Leucocintractia scleriae surround all peduncles of an infected inflorescence and by this character it differs from L. leucoderma and L. portus-argenti which sori surround the culms of the infected plants. Leucocintractia scleriae differs from L. pachyderma by having smaller spores (up to $17 \mu \mathrm{m}$ long versus 20-28 $\mu \mathrm{m}$ long for L. pachyderma) and thinner walls $(0.7-1.5 \mu \mathrm{m}$ thick versus $2.5-5 \mu \mathrm{m}$ thick for $L$. pachyderma).

Thirty-one species of smut fungi belonging to seven genera, Anthracoidea, Cintractia, Farysia, Moreaua, Schizonella, Tolyposporium, and Ustanciosporium, have been previously reported on host plants of Cyperaceae in Japan (Denchev 2015). A species of Leucocintractia is reported here for the first time from this country.

Acknowledgements. This research received support from the SYNTHESYS Project http:// www.synthesys.info/ which is financed by European Community Research Infrastructure Action under the FP7 "Capacities" Program.

\section{References}

Denchev, C.M. \& Denchev, T.T. 2012. New records of smut fungi. 6. - Mycotaxon 121: 215-223. http:// dx.doi.org/10.5248/121.215

Denchev, C.M., Denchev, T.T., Michikawa, M. \& Kakishima, M. 2011. Notes on some Japanese smut fungi. 5. Anthracoidea blepharicarpae and A. dispalatae, spp. nov. - Mycotaxon 115: 407-411. http:// dx.doi.org/10.5248/115.407

Denchev, T.T. 2015. [Taxonomic study of the smut fungi (Ustilaginomycetes) on Cyperaceae in Japan and South Korea]. PhD thesis. Institute of Biodiversity and Ecosystem Research, Bulgarian Academy of Sciences, Sofia. (In Bulgarian)

Denchev, T.T. \& Denchev, C.M. 2014. The genus Moreaua in Japan and Korea. - Mycotaxon 127: 73-80. http://dx.doi.org/10.5248/127.73

Denchev, T.T. \& Denchev, C.M. 2015. Ustanciosporium tropicoafricanum (Anthracoideaceae), a new smut fungus on Rhynchospora angolensis (Cyperaceae) from Zambia. - Nova Hedwigia. In press.

Denchev, T.T., Denchev, C.M., Michikawa, M. \& Kakishima, M. 2013. The genus Anthracoidea (Anthracoideaceae) in Japan and some adjacent regions. - Mycobiota 2: 1-125. http://dx.doi. org/10.12664/mycobiota.2013.02.01

Hoshino, T., Masaki, T. \& Nishimoto, M. 2011. Illustrated sedges of Japan. Heibonsha Ltd., Tokyo.

Lucero, L.E., Vegetti, A.C. \& Reinheimer, R. 2014. Evolution and development of the spikelet and flower of Rhynchospora (Cyperaceae). - International Journal of Plant Sciences 175: 186-201. http://dx.doi. org/10.1086/674317

Piepenbring, M., Begerow, D. \& Oberwinkler, F. 1999. Molecular sequence data assess the value of morphological characteristics for a phylogenetic classification of species of Cintractia. - Mycologia 91: 485-498. http://dx.doi.org/10.2307/3761349 
Piepenbring, M. 2003. Smut Fungi (Ustilaginomycetes p.p. and Microbotryales, Basidiomycota). - Flora Neotropica, Monograph 86: i-iv + 1-291.

Vánky, K. 2010. The smut fungi (Ustilaginomycotina) on Rhynchospora (Cyperaceae). - Mycologia Balcanica 7: 93-104.

Vánky, K. 2011 a. Seven new species of smut fungi (Ustilaginomycotina). - Mycologia Balcanica 8: 97-104. Vánky, K. 2011b['2012']. Smut fungi of the world. APS Press, St. Paul, Minnesota, USA.

Vánky, K. 2013. Illustrated genera of smut fungi. 3rd edn. APS Press, St. Paul, Minnesota, USA.

Vánky, K., Vánky, C. \& Denchev, C.M. 2011. Smut fungi in Africa - a checklist. - Mycologia Balcanica 8: $1-77$. 